\title{
RESEARCH PAPER \\ Prevalence and pathogenicity of fungi associated with grapevine trunk diseases in Chilean vineyards
}

\author{
Gonzalo A. Díaz ${ }^{1}$, Jaime Auger ${ }^{2}, X_{\text {Ximena Besoain }}^{3}$, Edmundo Bordeu ${ }^{1}$, and \\ Bernardo A. Latorre ${ }^{1}$ \\ ${ }^{1}$ Facultad de Agronomía e Ingeniería Forestal, Pontificia Universidad Católica de Chile, Casilla 306, \\ Santiago, Chile. \\ ${ }^{2}$ Facultad de Ciencias Agronómicas, Universidad de Chile, Casilla 1004, Santiago, Chile. \\ ${ }^{3}$ Facultad de Agronomía, Pontificia Universidad Católica de Valparaíso, Casilla 4-D, Quillota, Chile.
}

\begin{abstract}
G. A., Díaz, J., Auger, X., Besoain, E., Bordeu, and B. A. Latorre, 2013. Prevalence and pathogenicity of fungi associated with grapevine trunk diseases in Chilean vineyards. Cien. Inv. Agr. 40(2): 327-339. Trunk diseases in grapevine (Vitis vinifera) have been identified as a major problem in the wine and table grape industries around the world, reducing the productivity, quality and longevity of vineyards. The present study examined 694 wood samples from the cordons and trunks of vines with trunk disease symptoms in 67 Chilean vineyards located between Copiapó (27 $18^{\prime} \mathrm{S}$ ) and Los Angeles (3742' S). A total of 1,363 fungal isolates were obtained from diseased cordons and trunks with dark brown streaking, yellowish softspongy cankers and brown hard V-shaped cankers. Using molecular identification, a total of 12 fungal genera were identified in Chile at varying frequencies: Phaeomoniella chlamydospora (85\%); Botryosphaeriaceae (56\%) including Diplodia mutila, D. seriata, Neofusicoccum parvum and Spencermartinsia viticola; Inocutis sp. (47\%); Diatrypaceae (Cryptovalsa ampelina and Eutypella leprosa) (4.8\%); Seimatosporium botan (1.7\%); Phomopsis viticola (0.4\%); Cylindrocarpon sp. (0.4\%); and Phaeoacremonium aleophilum (0.2\%). All species were pathogenic, inducing dark brown streaking on various aged grapevine wood tissue. In conclusion, several fungal species are associated with grapevine trunk diseases in the Chilean vineyards being $\mathrm{Pa}$. chlamydospora, D. seriata and Inocutis sp. the most frequent isolated species. These are pathogens that can be found alone or they can coexist in the same plant. This is the first report of Pho. viticola associated with trunk diseases in Chile.
\end{abstract}

Key words: Botryosphaeria canker, Esca, fungal trunk pathogens, Vitis vinifera, wood decay.

\section{Introduction}

Grapevine (Vitis vinifera L.) is an important crop in Chile, with currently over 182,000 ha planted. In the past two decades, the importance of grapevine

Received January 31, 2013. Accepted July 3, 2013. Corresponding author: gonzdiaz@gmail.com trunk diseases in Chile has been recognized. It has recently been estimated that $22 \%$ of vineyards are affected, reducing productivity, quality and the productive lifespan of Chilean vineyards (Díaz et al., 2011a; Morales et al., 2012). Although symptoms can be observed in the trunks and cordons of young ( $<7$-year-old) grapevines, the prevalence and severity considerably increases as 
the vines get older (Bertsch et al., 2013; Morales et al, 2012; Úrbez-Torres, 2011).

Esca, Petri disease, black foot disease, Botryosphaeria dieback and Eutypa dieback are the predominant trunk diseases that affect vineyards worldwide (Bertsch et al., 2013; Halleen et al., 2006; Úrbez-Torres, 2011). However, only Botryosphaeria dieback, black dead arm and basal canker, and wood necrosis and dieback associated with diatrypaceous fungi and Seimatosporium botan have been reported among trunk diseases in Chile (Auger et al., 2004a; Auger et al., 2004b; Besoain et al., 2013; Díaz et al., 2011a,b, 2012; Latorre et al., 1986; Morales et al., 2012). In addition, chlorotic leaf roll similar to Eutypa dieback has been recognized in Chile (Auger et al., 2005).

Foliar symptoms include malformation, chlorosis and partial necrosis of the leaves associated with short internodes, reduced growth and a general decline. Wood symptoms are characterized by the presence of dark brown to black spots in crosssections of cordons and trunks, which are visible as dark brown wood streaking in longitudinal sections. In addition, brown hard V-shaped cankers and/or yellow soft cankers in the wood can also be observed (Cortesi et al., 2000; Bertsch et al., 2013, Mugnai et al., 1999; Úrbez-Torres et al., 2012; White et al., 2011a). The dark brown wood streaking associated to Esca-like symptoms is the most prevalent internal symptom in young and adult grapevines (Bertsch et al., 2013, Mugnai et al., 1999).

Several fungi are associated with trunk diseases throughout the world, including species of Ascomycetes, such as Botryosphaeriaceae spp., Diatrypaceae spp., Phaeoacremonium (Pm.) spp., Phaeomoniella (Pa.) chlamydospora, and Basidiomycetes, such as Fomitiporia (F.) punctata, F. mediterranea and Inocutis spp. (Armengol et al., 2001; Cortesi et al., 2000; Fisher, 2006; Martin and Cobos, 2007; Rolshausen et al., 2006; Taylor et al., 2005; Úrbez-Torres et al., 2012; White et al., 2011b).
In Chile, Botryosphaeria dothidea, Cryptovalsa (C.) ampelina, Diplodia (D.) seriata, D. mutila, Eutypella (Eu.) leprosa, Neofusicoccum (N.) parvum, Pm. aleophilum, Pa. chlamydospora, Seimatosporium (Se.) botan and Spencermartinsia (S.) viticola have been reported as associated with trunk diseases (Auger et al., 2004a; Auger et al., 2004b; Besoain et al., 2013; Díaz et al., 2009, 2011a,b, 2012; Latorre et al., 1986; Morales et al., 2012). Interestingly, Eutypa lata, which has been isolated from other grape-growing areas around the world, has not been reported in Chile.

Considering the importance of the grapevine industry in Chile, this study was conducted to identify the fungi associated with declining grapevines and to determine their relative importance and pathogenicity as fungal trunk pathogens in V. vinifera in Chile.

\section{Materials and methods}

\section{Sampling}

Sixty-seven vineyards in the main wine and table grapevine production valleys of Chile were surveyed from 2009 to 2012. Vineyards from 4 to 35 years old were sampled from Copiapó $\left(27^{\circ} 18^{\prime} \mathrm{S}\right)$ to Los Angeles (37 $42^{\prime}$ S), with a mean annual rainfall ranging from 1 to $1,000 \mathrm{~mm}$, most of which fell during the winter months. The samples consisted of at least 8-12 trunk and/or cordons per vineyard taken from diseased grapevines of wine and table grape cultivars with decline symptoms, including leaf malformation, chlorotic and necrotic leaves, short internodes, dead spurs and dieback.

\section{Fungal isolation}

The bark of each sample was removed prior to surface disinfection with $96 \%$ ethanol for $15 \mathrm{~s}$ and immediately flamed for $15 \mathrm{~s}$. The outer tissues were removed aseptically in a laminar flow chamber. Small wood pieces (3-5 mm) were taken 
from the margins between healthy and discolored tissues and placed in Petri dishes containing 2\% potato dextrose agar acidified with $0.5 \mathrm{ml} /$ liter of $92 \%$ lactic acid (APDA) plus $0.005 \%$ tetracycline, $0.01 \%$ streptomycin and $0.1 \%$ Igepal CO-630 (Sigma-Aldrich, MO, USA) (APDAm). The plates were incubated for 14 to 21 days at $20^{\circ} \mathrm{C}$ until fungal colonies were observed.

\section{Morphological and molecular identification}

Fungi were identified to the genus level on the basis of the culture characteristics and on the morphology of the asexual structures, including conidia, conidiophores and the presence or absence of fruiting bodies (Crous and Gams, 2000; Crous et al., 1996; Gottlieb et al., 2002; Hatakeyama and Harada, 2004; Mostert et al., 2006; Trouillas et al., 2010; Úrbez-Torres et al., 2006). One or two isolates of each fungal taxon were further identified to the species level by molecular analysis of the internal transcribed spacer (ITS1-5.8S-ITS2) region of the nuclear ribosomal DNA (rDNA). The rDNA was extracted from mycelium using a DNA extraction kit (Axygen Biosciences, CA, USA). The ITS region was amplified using ITS4 and ITS5 primers (White et al., 1990). Polymerase chain reactions (PCR) were conducted as previously reported (Úrbez-Torres et al., 2006) in a Maxygene Gradient thermal cycler (Axygen Biosciences, Union City, CA, USA). Each PCR reaction mixture contained $2.5 \mu \mathrm{L}$ of $10 \mathrm{x}$ PCR buffer, $1.0 \mu \mathrm{L}$ of $25 \mathrm{mM} \mathrm{MgCl}_{2}, 0.5 \mu \mathrm{L}$ of $10 \mathrm{mM}$
dNTPs, $0.5 \mu \mathrm{L}$ of $0.5 \mathrm{mM}$ of each primer, $0.2 \mu \mathrm{L}$ of Taq DNA polymerase (Invitrogen, Carlsbad, CA, USA) at 5 units $\mu \mathrm{L}^{-1}$, and $1 \mu \mathrm{L}$ of template DNA for a final volume of $25 \mu \mathrm{L}$. A negative control was included in each PCR reaction. The PCR products were separated on a $2 \%$ agarose gel in 1.0x Tris-acetate-EDTA (TAE) buffer and observed by UV illumination after staining with GelRedTM (Biotium Inc., Hayward, CA, USA). The PCR products were purified and sequenced in both directions by Macrogen (Macrogen Inc., Geumchen-gu, South Korea). The fungal sequences were manually- edited, assembled and aligned using Bioeditor version 7.1.3.0 (Tom Hall, Isis Pharmaceutical Inc., Carlsbad, CA, USA). Alignment gaps were treated as missing data. The sequences of each fungus were compared using the GenBank database and basic local alignment search tools (Blast) for nucleotide analyses. The identification was confirmed with $>98 \%$ similarity to the fungal species deposited in GenBank (Table 1).

\section{Pathogenicity tests}

The pathogenicity of one isolate from each identified species was tested in four independent experiments conducted on $V$. vinifera. The following isolates were used: C. ampelina (Cry-18-2009), D. mutila (Dm-25-2010), D. seriata (Ds-7-2009), Eu. leprosa (Eu-86-2010), N. parvum (Neo-105-2010), Pm. aleophilum (Pal-357-2010), Pa. chlamydospora (Pa.ch-3-2009), Phomopsis (Pho.) viticola (Pho-

Table 1. Isolates from GenBank used for nucleotide basic local alignment search tool (Blastn).

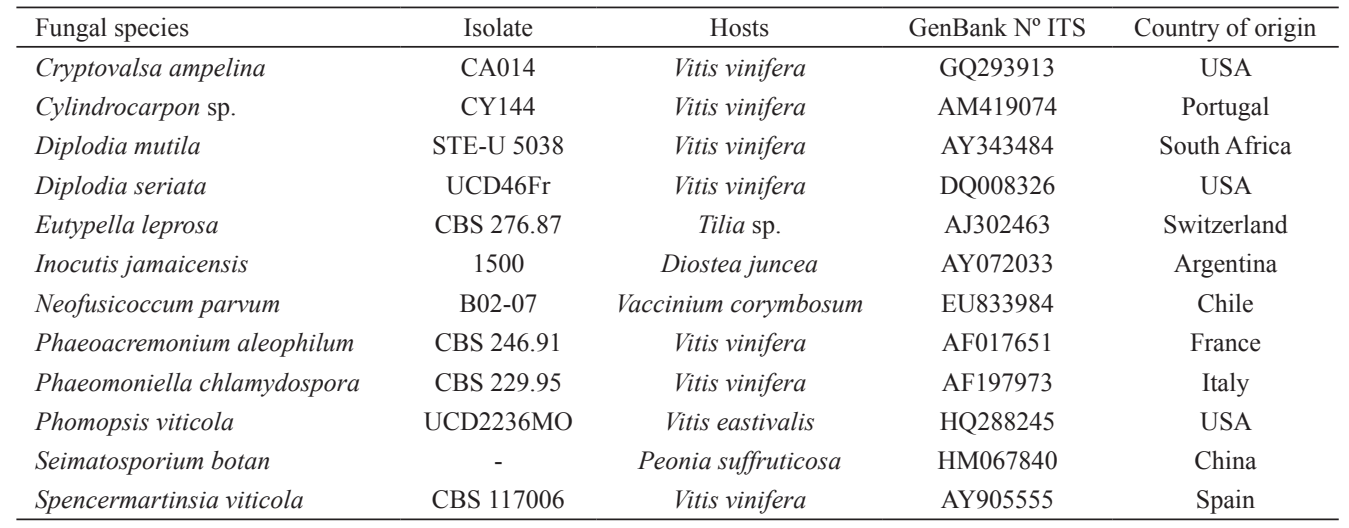


221-2010), Se. botan (Sei-302-2010), S. viticola (Spe-578-2011), Cylindrocarpon sp. (Cyl-476-2011) and Inocutis sp. (Bas-91-2010).

Axenic grapevine plantlets. Eight 30-day-old 'Carménère' plantlets that were $40 \mathrm{~mm}$ in height and six leaves, micropropagated on semisolid medium (Gregori and Tizio, 1997), were inoculated with a 2-mm-diameter mycelial plug from a 7- to 21-day-old APDA culture of each fungal isolate. The inoculum was placed upside down in a small injury ( $2 \mathrm{~mm}$ diameter) at the stem base that was made with a sterile scalpel. After inoculation, the inoculated site was left open. The plantlets were incubated under $200 \mu \mathrm{mol} \cdot \mathrm{m}^{2} \mathrm{~s}^{-1}$ of white fluorescent light for a 16 -h photoperiod at $20^{\circ} \mathrm{C}$ in a plant growth room. An equal number of plantlets that were inoculated with sterile agar were used as controls. The number of leaves, along with shoot and root lengths were assessed at 28 days post-inoculation. In an attempt to fulfill Koch's postulates, small pieces of colonized tissue taken from the margins of lesions were placed on APDAm.

Rooted grapevines. Five 'Carménère' vines (2 years old) were inoculated, during winter dormancy using a 5-mm-diameter mycelial plug from a 7- to 21-day-old APDA culture of each fungal isolate per vine, in a wound made with a 5-mm-diameter cork-borer into the trunk and sealed with Parafilm to avoid dehydration. An equal number of vines that were inoculated with sterile agar plugs were left as controls. All vines were maintained in a mixture of peat $(70 \%)$ and perlite $(30 \%)$ in $3.5 \mathrm{~L}$ containers in a lath house. The internal length of dark brown streaking was measured 15 mo post-inoculation. Re-isolations from the margins of dark brown streaking were performed by placing nine small wood pieces $(2 \times 2$ $\mathrm{mm}$ ) on APDAm per inoculated vine.

Grapevine shoots. Five green shoots per 8-yearold vine from the 'Cabernet Sauvignon' vineyard located in Alto Jahuel, Metropolitan Region, were aseptically wounded with a cork-borer (3-mmdiameter) at the third internode and inoculated with mycelial plugs from a 7- to 21-day-old APDA culture of each fungal isolate placed side down and wrapped with Parafilm to avoid dehydration in November (spring). One vine was selected per isolate. An equal number of shoots inoculated with sterile agar plugs were used as controls. Shoots were removed from the vines 60-days post-inoculation and taken to the laboratory for assessment by measuring the extent of the dark brown streaking from the inoculation site. Reisolations were performed from small pieces of the dark brown streaking that were placed on APDAm.

Detached grapevine shoots. Five 'Carménère' shoots (15-cm in length) obtained from a 12-yearold vineyard were disinfected superficially with $75 \%$ ethanol for $30 \mathrm{~s}$ and air dried in a laminar flow chamber. Wounds $(3 \times 3 \mathrm{~mm})$ were made with a cork-borer in the middle of the shoot and inoculated immediately with a $3 \times 3-\mathrm{mm}$ mycelium plug from a 7- to 21-day-old APDA culture of each fungal isolate per shoot. The control treatment was a sterile mycelium plug. The inoculated wounds were sealed with Parafilm to avoid dehydration. All shoots were placed in a humid chamber $(>85 \%$ relative humidity) $(35 \times 27 \times 13 \mathrm{~cm})$ at $25^{\circ} \mathrm{C}$. The dark brown streaking was measured at 14 days post-inoculation. Fungi were re-isolated from the margins of the dark brown streaking on the tissues and placed on APDAm.

\section{Design and statistical analysis}

Pathogenicity studies were performed using a completely randomized design with eight replicates for plantlet tests and five replicates for rooted grapevines, attached shoots and detached shoots. The results were subjected to an analysis of variance, and the means were separated according to a pairwise multiple comparison Tukey's test $(\mathrm{P}<0.05)$ using SigmaStat 3.1 (Systat Software Inc. San José, CA, USA). All experiments were repeated, except for the tests conducted with the rooted grapevines. 


\section{Results}

\section{Sampling and fungal isolation}

Cordons and trunks from young ( $\leq 10$ years old) grapevines mainly presented brown streaking that appeared as necrotic spots in cross-sections or dark brown streaking in longitudinal sections. Brown, hard, V-shaped cankers were sporadically observed in young grapevines. In addition to the dark brown streaking, yellowish soft, spongy cankers (Figure 1C) and/or a brown, hard, Vshaped cankers were commonly observed in the cross-sections of cordons and the trunks of mature ( $\geq 11$ years old) grapevines (Figure 1). Leaf malformation, chlorotic and necrotic leaves, short internodes, death of spurs and dieback were commonly associated with the cordon and/or trunk symptoms (Figure 2).

A total of 1,363 fungal isolates were obtained from 694 wood samples of diseased cordons and/ or trunks. A total of 12 genera were identified on the basis of their cultural and morphological characteristics. These genera included Cryptovalsa, Cylindrocarpon, Phomopsis (Diaporthe), Diplodia, Dothiorella, Eutypella, Inocutis, Neofusicoccum, Phaeoacremonium, Phaeomoniella, Seimatosporium and Spencermartinsia.

The analysis and comparison of the sequences of the ITS region of the rDNA with known sequences deposited in GenBank (Table 1) led to the identification of Pa. chlamydospora, Inocutis sp.; the Botryosphaeriaceae D. seriata, D. mutila, N. parvum and S. viticola; and the Diatrypaceae C. ampelina and Eu. leprosa. In addition, Se. botan, Pho. viticola, Cylindrocarpon sp. and Pm. aleophilum were also identified. The sequences of the Chilean isolates were deposited in GenBank (Table 2).

Overall, $85 \%$ of samples contained $P$ a. chlamydospora, followed by species of Botryosphaeriaceae (56\%) and Inocutis sp. (47\%) (Table 3). Other fungi were isolated only occasionally from diseased grapevine samples, including 4.8\% Diatrypaceae, $1.7 \%$ Se. botan, $0.4 \%$ Pho. viticola, $0.4 \%$ Cylindrocarpon sp. and $0.2 \% \mathrm{Pm}$. aleophilum.

Of the total isolates from samples affected by dark brown streaking ( $\mathrm{n}=657), P a$. chlamydospora was isolated from $85 \%$, including young and mature grapevine (Figure 1). Species of Botryosphaeriaceae, including $D$. mutila, $D$. seriata, $N$. parvum and $S$. viticola, were isolated
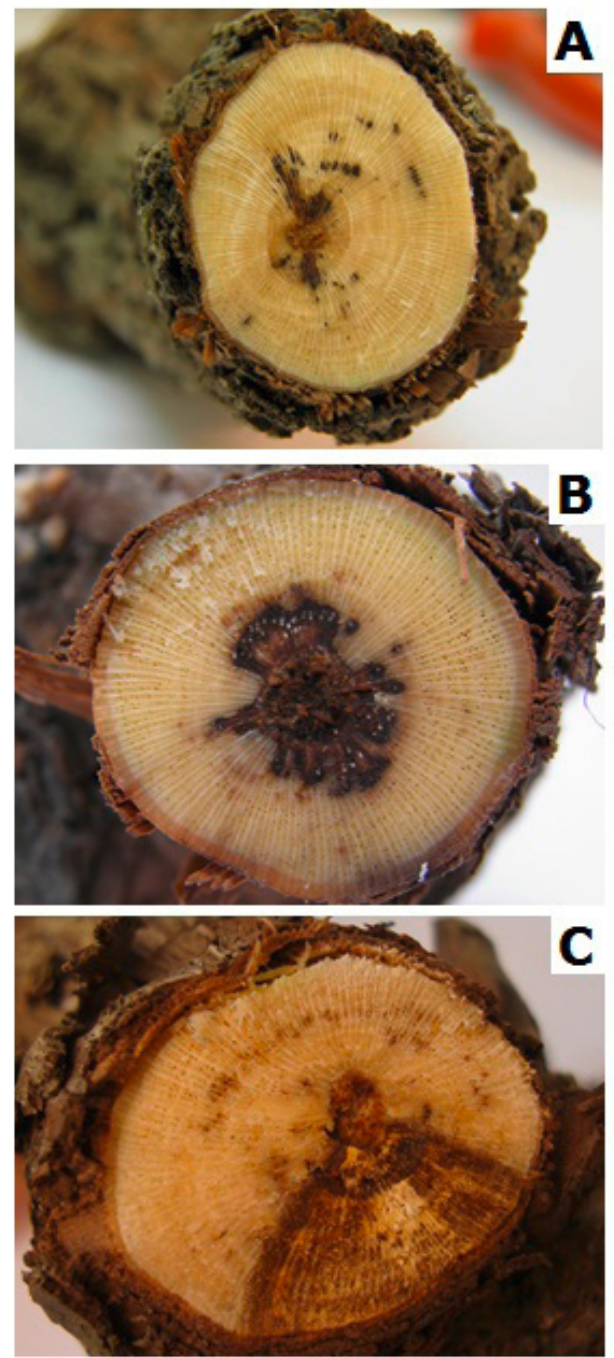

Figure 1. Cross-sections of diseased cordons or trunks with internal symptoms obtained from Chilean vineyards. A, Cordon of 8-year-old 'Carménère' vine with black spotting. B, Trunk of 15-year-old 'Carménère' vine with central black spotting. C, Cordon of 25-year-old 'Chardonnay' vine with canker with brown spotting and yellowish, soft and spongy rotten wood. 
Table 2. Fungal species obtained from Vitis vinifera with trunk diseases in Chile that were identified by Blast nucleotide analysis..

\begin{tabular}{|c|c|c|c|c|c|}
\hline Species & Isolate $^{1}$ & Host cultivars & Origin & $\begin{array}{c}\text { GenBank }{ }^{2} \\
\mathrm{~N}^{\mathrm{o}}\end{array}$ & $\begin{array}{l}\mathrm{IMI}^{3} \\
\mathrm{~N}^{\mathrm{o}}\end{array}$ \\
\hline Cryptovalsa ampelina & Cry-17 & Pinot Noir & Casablanca & HQ694976 & 398781 \\
\hline Cryptovalsa ampelina & Cry-18 & Cabernet Sauvignon & Alto Jahuel & HQ694977 & - \\
\hline Cylindrocarpon sp. & Cyl-476 & Cabernet Sauvignon & Nancagua & - & - \\
\hline Diplodia mutila & Dm-20 & Carménère & Alto Jahuel & - & - \\
\hline Diplodia mutila & Dm-5 & Cabernet Sauvignon & Alto Jahuel & - & - \\
\hline Diplodia seriata & Ds-7 & Cabernet Sauvignon & Alto Jahuel & - & - \\
\hline Diplodia seriata & Ds- 80 & Pinot Noir & Casablanca & - & - \\
\hline Eutypella leprosa & Eu-86 & Pinot Noir & Casablanca & HQ694974 & 398667 \\
\hline Eutypella leprosa & $\mathrm{Eu}-121$ & Chardonnay & Casablanca & HQ694975 & - \\
\hline Inocutis sp. & Bas-91 & Cabernet Sauvignon & Alto Jahuel & - & 399078 \\
\hline Inocutis sp. & Bas-184 & Cabernet Sauvignon & Nancagua & - & - \\
\hline Neofusicoccum parvum & Neo-104 & Syrah & Lolol & JF273631 & - \\
\hline Neofusicoccum parvum & Neo-105 & Cabernet Sauvignon & Lolol & JF273632 & - \\
\hline Phaeoacremonium aleophilum & Pal-357 & Cabernet Sauvignon & Nancagua & - & - \\
\hline Phaeomoniella chlamydospora & Pach-3 & Cabernet Sauvignon & Alto Jahuel & JF968607 & 397989 \\
\hline Phaeomoniella chlamydospora & Pach-55 & Pinot Noir & Mulchén & JF968608 & - \\
\hline Phomopsis viticola & Pho-210 & Carménère & Almahue & - & - \\
\hline Phomopsis viticola & Pho-221 & Cabernet Sauvignon & Almahue & - & - \\
\hline Seimatosporium botan & Sei-302 & Pedro Jimenez & Ovalle & JN088482 & - \\
\hline Seimatosporium botan & Sei-316 & Cabernet Sauvignon & Cauquenes & JN088483 & - \\
\hline Spencermartinsia viticola & Spe-578 & Carménére & Apalta & - & - \\
\hline Spencermartinsia viticola & Spe-643 & Cabernet Sauvignon & Alhué & - & - \\
\hline
\end{tabular}

${ }^{1}$ Isolate $=$ isolate code, specie-sample no.-collected year.

${ }^{2} \mathrm{GenBank}=$ isolates deposited in GenBank as accession number by ITS gen.

${ }^{3} \mathrm{IMI}=$ isolates deposited in $\mathrm{CABI}$ as IMI number.

Table 3. Frequency of fungal genera obtained from Vitis vinifera in the main grapevine production regions of Chile.

\begin{tabular}{|c|c|c|c|c|c|c|c|c|c|c|}
\hline \multirow[b]{2}{*}{ Region $^{1}$} & \multirow{2}{*}{$\begin{array}{c}\text { Total } \\
\text { samples }^{2} \\
\text { no. }\end{array}$} & \multirow{2}{*}{$\begin{array}{c}\text { Positive } \\
\text { sample, \% }\end{array}$} & $\mathrm{Pa}^{3}$ & $\mathrm{Bot}^{4}$ & $\mathrm{Ino}^{5}$ & $\mathrm{Dia}^{6}$ & $\mathrm{Sei}^{7}$ & $\mathrm{Pho}^{8}$ & $\mathrm{Cyl}^{9}$ & $\mathrm{~Pa}^{10}$ \\
\hline & & & \multicolumn{8}{|c|}{ Positive samples, no. } \\
\hline Copiapó & 16 & 93.8 & 0 & 14 & 6 & 0 & 0 & 0 & 0 & 0 \\
\hline Limarí & 68 & 100.0 & 58 & 12 & 9 & 0 & 5 & 0 & 0 & 2 \\
\hline Aconcagua & 40 & 97.5 & 32 & 18 & 13 & 0 & 0 & 0 & 0 & 0 \\
\hline Casablanca & 40 & 100 & 35 & 59 & 35 & 8 & 0 & 0 & 0 & 0 \\
\hline San Antonio & 26 & 76.9 & 19 & 2 & 0 & 0 & 0 & 0 & 0 & 0 \\
\hline Maipo & 182 & 100.0 & 168 & 88 & 85 & 12 & 0 & 3 & 2 & 0 \\
\hline Cachapoal & 36 & 100.0 & 23 & 35 & 25 & 5 & 0 & 0 & 0 & 0 \\
\hline Colchagua & 160 & 98.1 & 141 & 109 & 91 & 9 & 0 & 0 & 1 & 0 \\
\hline Curicó & 20 & 95.0 & 12 & 15 & 14 & 0 & 7 & 0 & 0 & 0 \\
\hline Maule & 40 & 100.0 & 35 & 28 & 35 & 0 & 0 & 0 & 0 & 0 \\
\hline Itata & 22 & 100.0 & 21 & 7 & 12 & 0 & 0 & 0 & 0 & 0 \\
\hline Bío-Bío & 44 & 95.5 & 36 & 36 & 3 & 0 & 0 & 0 & 0 & 0 \\
\hline Total & 694 & 97.9 & 590 & 391 & 328 & 34 & 12 & 3 & 3 & 2 \\
\hline$\%$ & - & - & 85.0 & 56.3 & 47.3 & 4.8 & 1.7 & 0.4 & 0.4 & 0.2 \\
\hline
\end{tabular}

${ }^{1}$ The regions were sorted by geographical location from north to south of Chile. ${ }^{2}$ Samples=Number cordons and/or trunks obtained from grapevine with trunk diseases. ${ }^{3} \mathrm{~Pa}=$ Phaeomoniella chlamydospora. ${ }^{4} \mathrm{Bot}=\mathrm{Botryosphaeriaceae} \mathrm{species;} \mathrm{Diplodia} \mathrm{seriata,} D$. mutila, Neofusicoccum parvum and Spencermartinsia viticola. ${ }^{5}$ Ino=Inocutis sp. ${ }^{6}$ Dia=Diatrypaceae species; Cryptovalsa ampelina and Eutypella leprosa $.{ }^{7} \mathrm{Sei}=$ Seimatosporium botan $.{ }^{8} \mathrm{Pho}=$ Phomopsis viticola $.{ }^{9} \mathrm{Cyl}=$ Cylindrocarpon $\mathrm{sp} .{ }^{10} \mathrm{Pal}=$ Phaeoacremonium aleophilum. 
from $91 \%$ of the samples exhibiting hard brown V-shaped cankers ( $\mathrm{n}=392)$. Diplodia seriata alone was isolated from $68 \%$ of the samples with a $\mathrm{V}$-shaped canker. Inocutis sp. was observed in $96 \%$ of the samples with yellowish soft-spongy cankers ( $\mathrm{n}=314)$ (Figures 1 and 3).

The Diatrypaceae species C. ampelina and Eu. leprosa were isolated from 1.8 and $2.9 \%$ of the samples with dark brown streaking, respectively. Seimatosporium botan was identified on $2.4 \%$ of samples with hard brown V-shaped cankers. Phaeoacremonium aleophilum, Pho. viticola and Cylindrocarpon sp. were isolated from $0.3-0.5 \%$ of the samples with dark brown streaking (Figure 3).

According to the distribution by valley, where the annual rainfall increases from 1 to $1,300 \mathrm{~mm}$ and annual temperature decreases from 18 to $11^{\circ} \mathrm{C}$, $\mathrm{Pa}$. chlamydospora was located from the north to the south of Chile and was found in all valleys except in Copiapó. Species of Botryosphaeriaceae were found in all valleys sampled, D. seriata was found in all valleys, and D. mutila, N. parvum and $S$. viticola only were obtained between the Casablanca and Curico Valleys (data not shown). The basidiomycete Inocutis sp. was isolated in all valleys, except in San Antonio (Table 3).

\section{Pathogenicity test}

All fungal species were pathogenic on axenic grapevine plantlets. Independent of the pathogen, the foliar symptoms consisted of shortened internodes and chlorosis and necrosis of the leaves

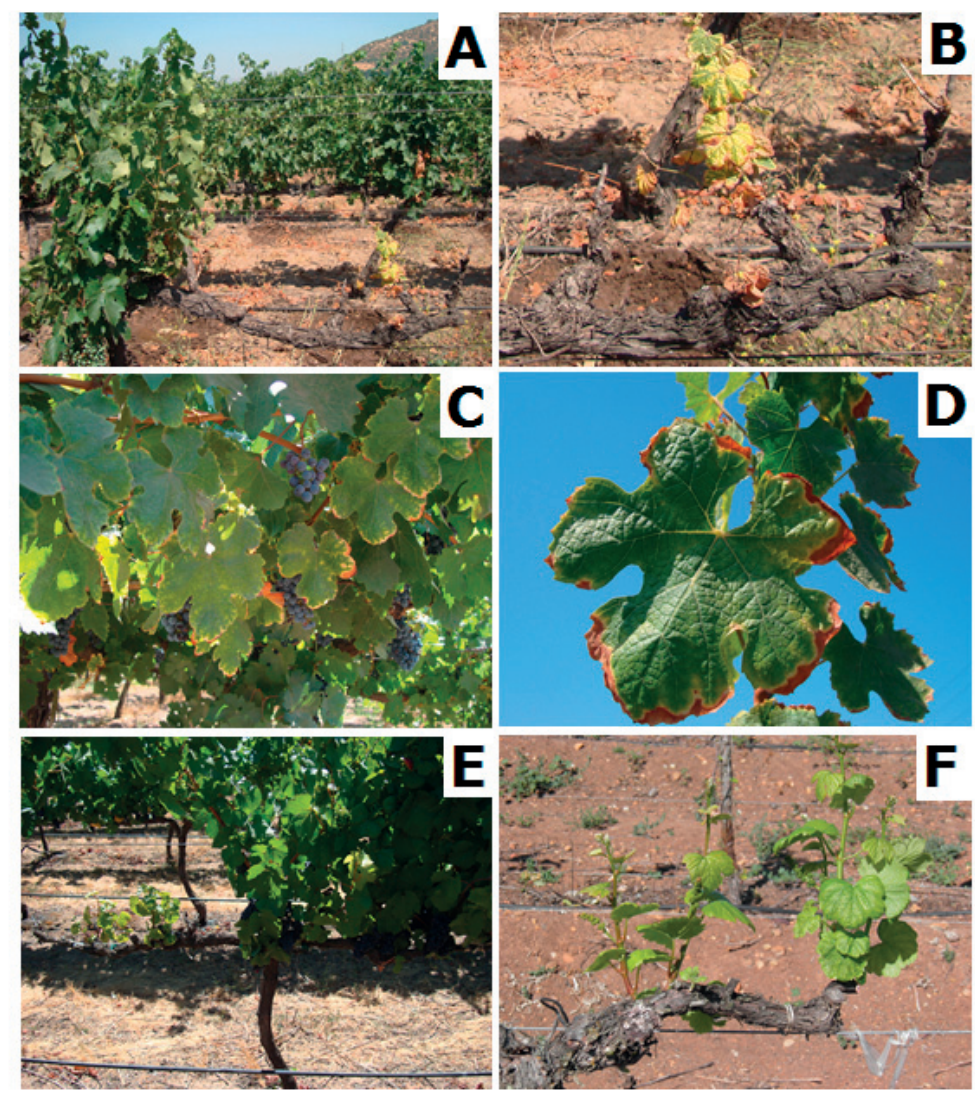

Figure 2. Decline symptoms observed in grapevines with trunk diseases in Chile. A-B, 'Cabernet Sauvignon' vine with diseased cordon, dead spurs, full chlorotic leaves, short internodes and stunted shoots. C-D, Shoots on 'Cabernet Sauvignon' vine with deformed necrotic leaves with marginal chlorosis. E, 'Pinot Noir' vine with cordon dieback. F, 'Chardonnay' vine cordon with cupped leaves. 
at 28 days post-inoculation. The non-inoculated grapevine plantlets remained healthy. The length of the roots, shoots and leaf numbers decreased significantly $(\mathrm{P} \leq 0.05)$ in inoculated grapevine plantlets (Table 4). Re-isolation was 100\% successful from inoculated grapevine plantlets, and pathogens were not re-isolated from non-inoculated controls.

All two-year-old grapevines inoculated with all fungal species developed brown streaking in the trunk. The length of the brown streaking varied among pathogens from $41.4 \mathrm{~mm}$ for $S$. botan to $109.9 \mathrm{~mm}$ for $N$. parvum after 15 months of incubation in lath-house conditions. Control treatments produced a slight discoloration (mean of $10.1 \mathrm{~mm}$ ) that was significantly different from the inoculated grapevines (Table 4). The pathogens were successfully re-isolated from more than $80 \%$ of the inoculated grapevines. No pathogens were isolated from non-inoculated controls.

Independent of the pathogens, significant $(\mathrm{P} \leq 0.05)$ brown streaking was obtained in inoculated shoots in the bioassay in the laboratory as well in inoculated shoots in the vineyard. In the laboratory, after 14 days at $25^{\circ} \mathrm{C}$, inoculated shoots developed vascular discoloration that varied from 11.3 to $79.6 \mathrm{~mm}$ for Inocutis sp. and N. parvum, respectively. Field-inoculated shoots developed brown streaking that varied from 15.5 for Pho. viticola to $81.1 \mathrm{~mm}$ for $N$. parvum after 60 days with mean air temperature of $18.7^{\circ} \mathrm{C}$ (Table 4). Re-isolations were successful in 60 to $100 \%$ of the inoculated shoots in the laboratory and in 89 to $100 \%$ of the field-inoculated shoots. Control treatments developed a slight discoloration in the detached shoots $(5.9 \mathrm{~mm})$ and in field shoot $(6.8 \mathrm{~mm})$, but no pathogens were isolated from these shoots.

\section{Discussion}

Trunk diseases were observed in vineyards located from the Copiapó valley in the north to the Bío-Bío valley in the south, which covers a distance of approximately $1,500 \mathrm{~km}$ in Chile. In the Copiapó valley, which is characterized by a desert climate, D. seriata and Inocutis sp. were

Table 4. Pathogenicity of fungal species associated with grapevine trunk diseases in Chile on axenic grapevine plantlets, 2-year-old grapevine trunks and attached and detached shoots from mature grapevines in the field.

\begin{tabular}{|c|c|c|c|c|c|c|}
\hline \multirow[b]{3}{*}{ Fungi } & \multicolumn{3}{|c|}{ Axenic plantlets } & \multirow{3}{*}{$\begin{array}{c}\text { Trunks } \\
\mathrm{BS}^{2}, \mathrm{~mm}\end{array}$} & \multicolumn{2}{|c|}{ Shoots } \\
\hline & \multirow{2}{*}{$\begin{array}{c}\text { Roots }^{1} \\
\mathrm{~mm}\end{array}$} & \multirow{2}{*}{$\begin{array}{c}\text { Shoots }^{1} \\
\mathrm{~mm}\end{array}$} & \multirow{2}{*}{$\begin{array}{c}\text { Leaves }^{1} \\
\text { no. }\end{array}$} & & Detached & Attached \\
\hline & & & & & \multicolumn{2}{|c|}{$\mathrm{BS}^{2}, \mathrm{~mm}$} \\
\hline Cryptovalsa ampelina & $58.5 \mathrm{bc}$ & $61.9 \mathrm{bc}$ & $7 \mathrm{ab}$ & $57.1 \mathrm{bcd}$ & $14.1 \mathrm{~b}$ & $18.6 \mathrm{~b}$ \\
\hline Cylindrocarpon sp. & $65.8 \mathrm{~cd}$ & $69.2 \mathrm{~cd}$ & $12 \mathrm{~d}$ & nd & nd & nd \\
\hline Diplodia mutila & $48.9 \mathrm{ab}$ & $49.6 \mathrm{ab}$ & $7 \mathrm{ab}$ & $77.7 \mathrm{de}$ & 39.9 ef & $63.9 \mathrm{e}$ \\
\hline Diplodia seriata & $62.6 \mathrm{bc}$ & $58.9 \mathrm{c}$ & $11 \mathrm{~cd}$ & $72.1 \mathrm{cde}$ & $53.5 \mathrm{~g}$ & $64.3 \mathrm{e}$ \\
\hline Eutypella leprosa & $58.8 \mathrm{bc}$ & $63.2 \mathrm{c}$ & $7 \mathrm{ab}$ & $51.4 \mathrm{~b}$ & $33.2 \mathrm{de}$ & $33.1 \mathrm{c}$ \\
\hline Inocutis sp. & $74.2 \mathrm{de}$ & $73.9 \mathrm{~cd}$ & $11 \mathrm{~cd}$ & $53.1 \mathrm{bc}$ & $11.3 \mathrm{ab}$ & $19.1 \mathrm{~b}$ \\
\hline Neofusicoccum parvum & $41.5 \mathrm{a}$ & $38.4 \mathrm{a}$ & $6 \mathrm{a}$ & $109.9 \mathrm{f}$ & $79.6 \mathrm{i}$ & $81.1 \mathrm{f}$ \\
\hline Phaeoacremonium aleophilum & $64.3 \mathrm{~cd}$ & $68.5 \mathrm{~cd}$ & $10 \mathrm{bcd}$ & nd & $24.7 \mathrm{c}$ & nd \\
\hline Phaeomoniella chlamydospora & $63.4 \mathrm{bc}$ & $65.7 \mathrm{c}$ & $10 \mathrm{bcd}$ & $88.0 \mathrm{e}$ & $43.8 \mathrm{f}$ & $45.0 \mathrm{~d}$ \\
\hline Phomopsis viticola & $80.4 \mathrm{e}$ & $78.6 \mathrm{~d}$ & $10 \mathrm{bcd}$ & nd & $12.1 \mathrm{ab}$ & $15.5 \mathrm{~b}$ \\
\hline Seimatosporium botan & $62.7 \mathrm{~cd}$ & $62.1 \mathrm{bc}$ & $8 \mathrm{abc}$ & $41.4 \mathrm{~b}$ & $29.8 \mathrm{~cd}$ & $37.1 \mathrm{c}$ \\
\hline Spencermartinsia viticola & $42.1 \mathrm{a}$ & $42.8 \mathrm{a}$ & $6 \mathrm{a}$ & $89.9 \mathrm{ef}$ & $71.9 \mathrm{~h}$ & $60.2 \mathrm{e}$ \\
\hline Control & $122.4 \mathrm{f}$ & $124.9 \mathrm{e}$ & $15 \mathrm{e}$ & $10.1 \mathrm{a}$ & $5.9 \mathrm{a}$ & $6.8 \mathrm{a}$ \\
\hline
\end{tabular}

${ }^{1}$ Mean length of roots, shoots and leaves of axenic 'Carménère' grapevine plantlets. ${ }^{2} \mathrm{BS}=$ Mean length of brown streaking. Means followed by the same letters in each column did not differ significantly according to Tukey's pairwise multiple comparison test $(\mathrm{P}=0.05)$. nd $=$ not determined. 
found, but no evidence of Pa. chlamydospora was obtained. However, Pa. chlamydospora was the most frequently isolated species in the valleys that are characterized by rather humid conditions, whereas in central Chile (Aconcagua to Colchagua valleys) with a cool Mediterranean climate, a great diversity of fungi were found associated with trunk diseases of grapevines. Vineyards in San Antonio Valley are relatively young, and this may explain the low isolation frequency of fungal trunk pathogens obtained in this study. Phaeomoniella chlamydospora, Botryosphaeriaceae spp. and Inocutis sp. were also detected in the valleys located in south-central Chile between Curicó and Bío-Bío, which is associated with a Mediterranean to humid temperate climate.

The present study reports 12 different fungal taxa associated with trunk diseases in Chilean vineyards. These results are in agreement with those reported in Argentina (Gatica et al., 2000), France (Larignon and Dubos, 1997), Italy (Mugnai et al., 1999), the USA (Úrbez-Torres et al., 2012), Spain (Armengol et al., 2001; Martin and Cobos,
2007) and South Africa (White et al., 2011b) where trunk diseases are associated with up to 16 different fungal species. However, the relative prevalence of each taxon varied by country.

On the basis of these results, the most frequently isolated species was $P a$. chlamydospora, followed by species of Botryosphaeriaceae and Inocutis sp. Similar results were reported in Italy and Spain, where Pa. chlamydospora was the most frequent species associated with grapevine trunk diseases (Martin and Cobos, 2007; Mugnai et al., 1999). However, species of the families Diatrypaceae and Botryosphaeriaceae have been reported as the main fungal pathogens associated with grapevine trunk diseases in Australia and California (Pitt et al., 2010; Trouillas et al., 2010; Trouillas et al., 2011; Úrbez-Torres et al., 2006).

Similar to other grapevine-producing regions of the world (Martin and Cobos, 2007; Mugnai et al., 1999; Úrbez-Torres et al., 2012), Pa. chlamydospora has been associated with dark brown streaking that appears in very young grapevines,
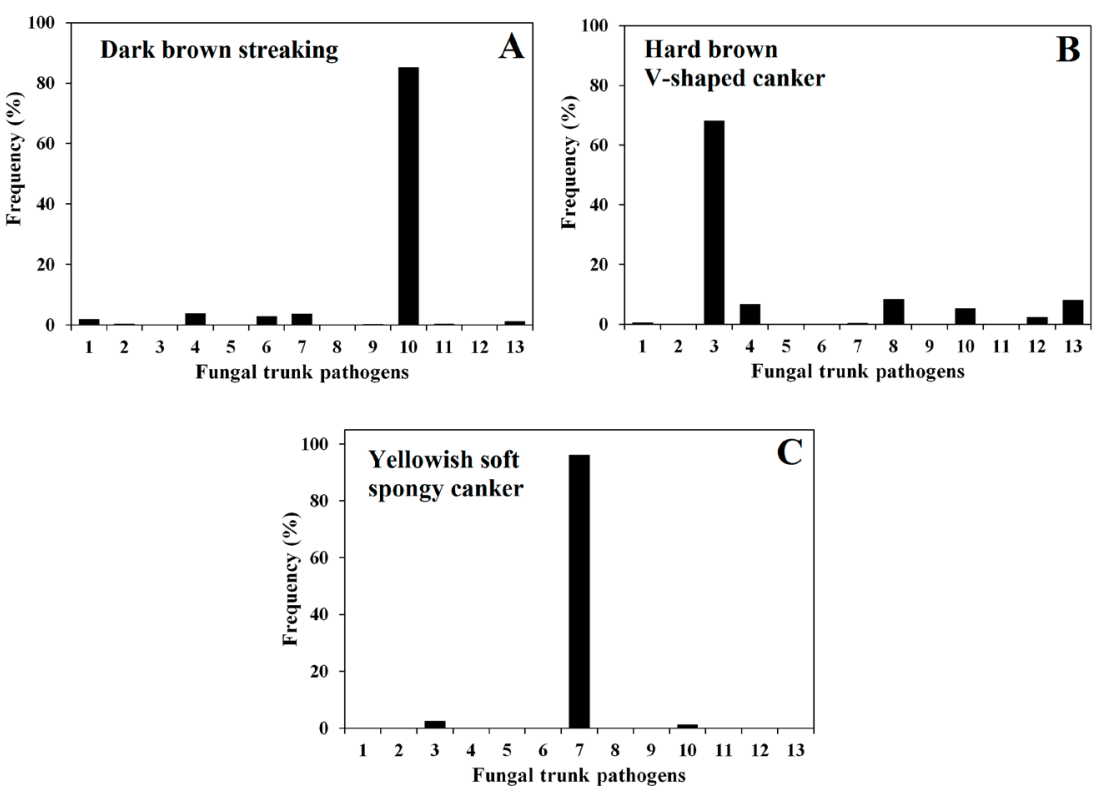

Figure 3. Frequency of fungal species obtained from samples according to wood canker type. A, Frequency according to presence of dark brown streaking canker $(n=657$ isolates). B, Frequency according to presence of hard brown $\mathrm{V}$-shaped canker ( $\mathrm{n}=392$ isolates). C, Frequency according to presence of yellowish soft-spongy canker ( $\mathrm{n}=314$ isolates). 1, Cryptovalsa ampelina; 2, Cylindrocarpon sp.; 3, Diplodia seriata; 4, Diplodia mutila; 5, Eutypa lata; 6, Eutypella leprosa; 7, Inocutis sp.; 8, Neofusicoccum parvum; 9, Phaeoacremonium aleophilum; 10, Phaeomoniella chlamydospora; 11, Phomopsis viticola; 12, Seimatosporium botan; 13, Spencermartinsia viticola. 
even at nurseries. The Botryosphaeriaceae species were mainly isolated from hard brown $\mathrm{V}$-shaped cankers that developed primarily in relatively older ( $>7$-year-old) plants. Several other studies have also associated Botryosphaeriaceae spp. with V-shaped cankers (Auger et al., 2004a; Morales et al., 2012; Úrbez-Torres et al., 2012; White et al., 2011a).

On the basis of morphology and ITS analysis, it was impossible to identify the species of the Chilean isolates of Inocutis. These Inocutis isolates were only obtained from yellowish soft-spongy cankers that were observed in grapevines over 10 years old. Other studies have demonstrated that basidiomycete fungi attack relatively old grapevine wood (Cortesi et al., 2001). Fomitiporella vitis, a basidiomycete fungus previously associated to chlorotic leaf roll in Chile (Auger et al., 2005), and other species of Fomitiporella were absent in this study, but these results do not exclude that these pathogens may be present in Chilean vineyards.

On the other hand, Diatrypaceae species, including C. ampelina and Eu. leprosa, were mainly obtained at a relatively low frequency from brown wood streaking. Previously, C. ampelina isolates have been obtained from hard brown cankers and brown vascular streaking (Díaz et al., 2011b). Seimatosporium botan was isolated from hard brown cankers (Díaz et al., 2012). For the first time, Pho. viticola was isolated from the dead arms of grapevines in Chilean vineyards. Previously, Pho. viticola was reported only as a foliar and fruit pathogen of grapevines in Chile (Acuña, 2010). However, the relative importance of these pathogens varies considerably from other vineyards worldwide (Armengol et al., 2001, Laringnon and Dubos, 1997; Pitt et al., 2010; Rolshausen et al., 2006; Trouillas et al., 2010; White et al., 2011b).

Several studies have reported that Phaeoacremonium spp. is an important fungi associated with the trunk diseases of grapevines (Armengol et al., 2001; Bertsch et al., 2013; Mugnai et al., 1999; Mostert et al., 2006). However, Pm. aleophilum was occasionally isolated in northern Chile in this study.

Regardless of the fungal species, all fungal isolates were pathogenic when they were tested in axenic 'Carménère' grapevine plantlets, but the symptoms varied among pathogen species from leaf chlorosis (e.g., Inocutis sp.) and reddening (e.g., Pa. chlamydospora) to a rapid death (e.g., Botryosphaeriaceae spp.) of the entire plantlets. These results were similar to those obtained by Gatica et al. (2000) working with 'Cabernet Sauvignon', 'Malbec' and 'Tempranillo' grapevines plantlets inoculated with I. jamaicensis (=Phellinus sp.), Pa. chlamydospora and Botryosphaeriaceae sp. The inoculated trunks of young grapevines displayed brown streaking lesions that varied in length from $41 \mathrm{~mm}$ (Se. botan) to $109 \mathrm{~mm}$ (N. parvum). Foliar symptoms, chlorosis and/or reddish leaves were only produced by Pa. chlamydospora, Inocutis sp. and Diatrypaceae spp., and no foliar symptoms were observed when grapevine plantlets were inoculated with Botryosphaeriaceae spp. and Se. botan (Úrbez-Torres, 2011). Pathogenicity was also demonstrated on inoculated shoots in bioassays as well in inoculated shoots in the vineyards, but only the induction of brown streaking was observed. In agreement with previous studies, the Botryosphaeriaceae species were the most virulent pathogens isolated in this study (ÚrbezTorres et al., 2012).

Samples of grapevines presenting chlorotic leaf roll, a grapevine disease previously described in Chile (Auger et al., 2005), were analyzed in this study. However, the symptoms of chlorotic leaf roll were not induced in artificially inoculated plants in this study. Based on our results, it is very possible that several fungal trunk pathogens can be associated with chlorotic leaf roll, including Inocutis sp., Fomitiporella spp., Pa. chlamydospora, Pm. aleophilum and Diatrypaceae species. However, further research is needed to clarify the role of the pathogens identified in this study in the etiology of chlorotic leaf roll. In addition, E. lata, a pathogen inducing symptoms similar 
to those described for chlorotic leaf roll (Bertsch et al., 2013; Pitt et al., 2010) was not identified in this study. To our knowledge, E. lata is absent in Argentina where "hoja de malvón," a disease similar to chlorotic leaf roll, has been described on grapevines (Gatica et al., 2000).

In conclusion, several fungal species are associated with grapevine trunk diseases in the Chilean vineyards, with $P a$. chlamydospora, $D$. seriata and Inocutis sp. being the most frequent isolated species. These pathogens can be found alone, or they can coexist in the same plant. The tiger stripe foliar symptoms that were previously described for Esca disease were not observed in this study (Mugnai et al., 1999; White et al., 2011b). Interestingly, Eutypa dieback (E. lata), which is commonly found in other grape-growing areas of the world, was not identified in this study. Accepting that the climatic conditions in central and southern Chile are not a limiting factor for E. lata, and considering that the long-distance dissemination of E. lata only occurs in association with infected plant materials, it is possible that this pathogen has not yet been introduced into the country.

\section{Resumen}

G.A., Díaz, J., Auger, X., Besoain, E., Bordeu y B.A. Latorre. 2013. Prevalencia y patogenicidad de hongos asociados con enfermedades de la madera en viñedos Chilenos. Cien. Inv. Agr. 40(2): 327-339. Las enfermedades de la madera de la vid (Vitis vinifera) se han identificado como un importante problema sanitario de la industria vitícola en el mundo, reduciendo la productividad, calidad y longevidad de los viñedos. En el presente estudio se examinó 694 muestras de brazos y troncos de vides con cancrosis en la madera recolectada en 67 viñedos entre Copiapó ( $27^{\circ} 18^{\prime}$ S) y Los Ángeles ( $37^{\circ} 42^{\prime}$ S), Chile. Se obtuvieron 1.363 aislados fúngicos desde brazos y troncos enfermos, caracterizados por presentar estrías necróticas vasculares, cancros blandos, esponjosos, blanco-cremosos y cancros firmes en consistencia, pardos, a menudo en forma de V e cortes transversales. Por análisis molecular de la región ITS del ADNr, se identificaron 12 géneros de hongos fitopatógenos los correspondieron a: Phaeomoniella chlamydospora (85\%), especies de Botryosphaeriaceae (56\%) (Diplodia mutila, D. seriata, Neofusicoccum parvum y Spencermartinsia viticola), Inocutis sp. (47\%), Diatrypaceae spp. (Cryptovalsa ampelina y Eutypella leprosa) (4,8\%), Seimatosporium botan (1,7\%), Phomopsis viticola (0,4\%), Cylindrocarpon sp. $(0,4 \%)$ y Phaeoacremonium aleophilum (0,2\%). Estas especies fueron patogénicas, induciendo estrías necróticas vasculares, pardo oscuras, a negras en tejidos semi-lignificados y lignificados de vid. En conclusión, varias especies de hongos fitopatógenos están asociados a cancrosis de la madera en viñedos siendo Pa. chlamydospora, D. seriata e Inocutis sp. las especies mas frecuentemente encontradas. Estos hongos fitopatógenos pueden encontrarse solos o se pueden encontrar coexistiendo en la misma planta. Este es el primer reporte de Pho. viticola asociado con enfermedades de la madera en Chile.

Palabras clave: Esca, hongos de la madera, pudrición de la madera. 


\section{References}

Acuña, R. 2010. Compendio de bacterias y hongos de frutales y vides en Chile. Servicio Agrícola y Ganadero (SAG). 150 p. Available online at: www.sag.cl (Website accessed: June 30, 2013).

Armengol, J., Vicent, A., Torne, L., García-Figueres, F., and García-Jiménes, J. 2001. Fungi associated with esca and grapevine declines in Spain: a three-year survey. Phytopathol. Mediterr. 40:S325S329

Auger, J., N. Aguilera, and M. Esterio. 2005. Identification of basidiomycete species associated with wood decay symptoms of grapevine chlorotic leaf roll in Chile. Phytopathol. Mediterr. 44: 86-86.

Auger, J., M. Esterio, G. Ricke, and I. Pérez. 2004a. Black dead arm and basal canker of Vitis vinifera cv. Red Globe caused by Botryosphaeria obtusa in Chile. Plant Dis. 88:1286-1286.

Auger, J., I. Pérez, M. Esterio, W.D. Gubler, and A. Eskalen. 2004b. First report of Phaeomoniella chlamydospora on Vitis vinifera and French American hybrids in Chile. Plant Dis. 88:12851285.

Besoain, X., C. Torres, G.A. Díaz, and B.A. Latorre. 2013. First report of Neofusicoccum australe associated with Botryophaeria canker of grapevine in Chile. Plant Dis. 97:143-143.

Bertsch, C., M. Ramírez-Suero, M. Magnin-Robert, P. Larignon, J. Chong, E. Abou-Mansour, A. Spagnolo, C. Clément, and F. Fontaine. 2013. Grapevine trunk diseases: complex and still poorly understood. Plant Pathol. 62:243-265.

Cortesi, P., M. Fischer, and M.G. Milgroom. 2000. identification and spread of Fomitiporia punctata associated with wood decay of grapevine showing symptoms of esca. Phytopathology 90:967-972.

Crous, P., and W. Gams. 2000. Phaeomoniella chlamydospora gen. et comb. nov., a causal organism of Petri grapevine decline and esca. Phytopathol. Mediterr. 39:112-118.

Crous, P., W. Gams, M. Wingfield, and P.S. Van Wyk. 1996. Phaeoacremonium gen. nov. associated with wilt and decline diseases of woody host and human infections. Mycologia 88:786-796.
Díaz, G.A., K. Elfar, and B.A. Latorre. 2012. First report of Seimatosporium botan associated with trunk disease of grapevine (Vitis vinifera) in Chile. Plant Dis. 96:1696-1696.

Díaz, G.A., M. Esterio, and J. Auger. 2009. Effects of Phaeomoniella chlamydospora and Phaeoacremonium aleophilum on grapevine rootstocks. Cien. Inv. Agr. 36:381-390.

Díaz, G.A., D. Prehn, X. Besoain, E.R. Chávez, and B.A. Latorre. 2011a. Neofusicoccum parvum associated with grapevine trunk diseases in Chile. Plant Dis. 95:1032-1032.

Díaz, G.A., D. Prehn, and B.A. Latorre. 2011b. First report of Crytovalsa ampelina and Eutypella leprosa associated with grapevine trunk diseases in Chile. Plant Dis. 95:490-490.

Fischer, M. 2006. Biodiversity and geographic distribution of basidiomycetes causing esca-associated white rot in grapevine: a worldwide perspective. Phytopathol. Mediterr. 45:S30-S42.

Gatica, M., B. Dubos, and P. Larignon. 2000. The 'hoja de malvón' grape disease in Argentina. Phytopathol. Mediterr. 39:41-45.

Gottlieb, A.M., J.E. Wright, and J.M. Moncalvo. 2002. Inonotus s.1. in Argentina-morphology, cultural characters and molecular analyses. Mycol. Prog. 1:299-313.

Gregori, M.T., and R. Tizio. 1997. Effect of the mycelium, diffused substances and extract of the fungus Cladosporium herbarum (Pers.) Link on the in vitro and in vivo growth of grapevine (Vitis vinifera L.) cv. Cabernet Sauvignon. Vitis 36:61-65.

Hatakeyama, S., and Y. Harada. 2004. A new species of Dicostroma and its anamorph Seimatosporium with two morphological types of conidia, isolated from stems of Peonia suffruticosa. Mycoscience 45:106-111.

Latorre, B.A., X. Besoaín, and V. Flores. 1986. Botryosphaeria canker of table grapes. Phytopatho$\operatorname{logy} 76: 1112$.

Larignon, P., and B. Dubos. 1997. Fungi associated with esca disease in grapevine. Eur. J. Plant Pathol. 103:147-157.

Martin, M.T., and R. Cobos. 2007. Identification of fungi associated with grapevine decline in 
Castilla y León (Spain). Phytopathol. Mediterr. 46:18-25.

Morales, A., B.A. Latorre, E. Piontelli, and X. Besoain. 2012. Botryosphaeriaceae species affecting table grapes vineyards in Chile and cultivar susceptibility. Cien. Inv. Agr. 39:445-458.

Mostert, L., J. Groenewald, R. Summerbell, W. Gams, and P. Crous. 2006. Taxonomy and pathology of Togninia (Diaporthales) and its Phaeoacremonium anamorphs. Studies in Mycology 54:1-125.

Mugnai, L., A. Graniti, and G. Surico. 1999. Esca (black measles) and brown wood-streaking: Two old and elusive diseases of grapevines. Plant Dis. 83:404-418.

Pitt, W.M., R. Huang, F.P. Trouillas, C.C. Steel, and S. Savocchia. 2010. Evidence that Eutypa lata and others diatrypaceous species occur in New South Wales vineyards. Aust. Plant Pathol. 39:97-106.

Rolshausen, P., N.E. Mahoney, R.J. Molyneux, and W.D. Gubler. 2006. A reassessment of the species concept in Eutypa lata, the causal agent of eutypa diaback of grapevine. Phytopathology 96:369-377.

Taylor, A., G.E. Hardy, P. Wood, and T. Burgess. 2005. Identification and pathogenicity of Botryosphaeria species associated with grapevine decline in Western Australia. Aust. Plant Pathol. 34:187-195.

Trouillas, F.P., J.R. Úrbez-Torres, and W.D. Gubler. 2010. Diversity of diatrypaceous fungi associated with grapevine canker diseases in California. Mycologia 102:319-336.
Trouillas, F.P., W.M. Pitt, M.R. Sosnowski, R. Huang, F. Peduto, A. Loschiavo, S. Savocchia, E.S. Scott, and W.D. Gubler. 2011. Taxonomy and DNA phylogeny of Diatrypaceae associated with Vitis vinifera and other woody plant in Australia. Fungal Divers. 49:203-223.

Úrbez-Torres, J.R. 2011. The status of Botryosphaeriaceae species infecting grapevines. Phytopathol. Mediterr. 50:S5-S44.

Úrbez-Torres, J.R., F. Peduto, R.K. Striegler, K.E. Urrea-Romero, J.C. Rupe, R.D. Cartwrigth, and W.D. Gubler. 2012. Characterization of fungal pathogens associated with grapevine trunk diseases in Arkansas and Missouri. Fungal Divers. 52:169-189.

Úrbez-Torres, J.R., G.M. Leavitt, T.M. Voegel, and W.D. Gubler. 2006. Identification and distribution of Botryosphaeria spp. associated with grapevine cankers in California. Plant Dis. 90:1490-1503.

White, T.J., T. Bruns, S. Lee, and J. Taylor. 1990. Amplification and direct sequencing of fungal ribosomal RNA genes for phylogenetics. Pages 315-322. PCR, A Guide to methods and applications. In: M.A. Innis, D.H. Gelfand, J.J. Snisky, and T.J. White, (eds.). Academic Press, San Diego, CA.

White, C. L., F. Halleen, M. Fisher, and L. Mostert, L. 2011a. Characterization of the fungi associated with esca diseased grapavines in South Africa. Phytopathol. Mediterr. 50: 204-223.

White, C. L., F. Halleen, and L. Mostert. 2011b. Symptoms and fungi associated with esca in South African vineyards. Phytopathol. Medirerr. 50:S236-S246. 
